\title{
CHARACTERIZATION OF BUCKWHEAT GRAIN PROTEINS AND ITS PRODUCTS
}

\author{
E. AUBRECHT and P. Á. BIACS \\ Central Food Research Institute, H-1022 Budapest, Herman Ottó út 15. Hungary
}

(Received: 22 March 2000; accepted: 19 September 2000)

Immunological assays demonstrate that buckwheat flour proteins present no toxic prolamins to coeliac patients.

Our study proves that buckwheat has no homologous protein structure with wheat. Electrophoretograms showed that some protein bands of buckwheat proteins resemble papillionaceous (bean) proteins.

The allergenic character of buckwheat was measured by competitive indirect ELISA using anti-wheat germ lectin (Wga) immune serum. Properly hulled buckwheat flour did not react with Wga immune serum, and is therefore suitable to be used in the diet of coeliac patients.

Keywords: buckwheat, homologous protein structure, cross-reaction, sensitize

Major endosperm proteins of buckwheat Fagopyrum esculentum (MOENCH) are salt soluble globulins (TIARA, 1974, HILLER et al., 1975, MAKSIMOVIC et al., 1996). The main seed storage protein of buckwheat is the $13 \mathrm{~S}$ globulin. It has a hexamer structure with subunits composed of dissolved bonded acidic and basic polypeptides, the structure common to all legumin-like storage proteins (MAKSIMOVIC et al., 1996). Vicillin-like proteins of buckwheat are 57-58 kDa polypeptides, which constitute $6.5 \%$ of total seed proteins (RADOVIC et al., 1999).

Protein content of buckwheat flour is ranging from 8.51 to $15.87 \%$ depending on variety (FRANCISCHI et al., 1994a). The main difference regarding protein fractions between buckwheat flour and wheat flour is that buckwheat is rich in albumin and globulin, but very low in prolamin (average 1.9\% only) and glutelin content is also much lower than that of wheat flour. The quantity and ratio of individual protein fractions vary in a large range depending on varieties. This is valid for albumin and globulin (WEI et al., 1995). Compared with wheat flour protein, buckwheat proteins show a higher or similar content of nearly all amino acids except for glutamine and proline, the percentages of which are much lower than in wheat flour. Percentage of all 
other essential amino acids is higher than or near to that of wheat protein (WEI et al., 1995). Particularly the content of the limiting amino acid lysine is 2.5 times higher than in wheat flour.

Buckwheat grains and buckwheat products have high nutritive value. Buckwheat noodles are favourite food in some countries and are also used for some diet due to their curative and healthy effects (WEI et al., 1995).

Limitations in terms of classification of buckwheat or other seed proteins based on solubility only to gluten proteins (JAVORNIK et al., 1981; IKEDA et al., 1991) is unfortunate and can lead to unnecessary exclusion of valuable sources of dietary protein in gluten-sensitive individuals (SKERRITT, 1986). Buckwheat flour is suitable for use in coeliac diet, since its prolamin content is low. In addition, immunological assays revealed that the buckwheat contains no toxic prolamins to coeliac disease patients (FRANCISCHI, 1994b).

The antinutritive and allergic characters of buckwheat have not yet been elicited entirely. KONDO and co-workers (1996) studied the allergic properties of protein. A $24 \mathrm{kDa}$ buckwheat protein was shown by immunoblotting analysis to be the most frequently recognised allergic component.

The aim of research to be presented in this paper was to test the presence of homologous structure of wheat and legume proteins with buckwheat flour proteins; to study prolamin content of buckwheat with immunochemical method; to measure the quantity of homologous protein structure of buckwheat inner layer membrane with wheat germ agglutinin immune serum by competitive indirect ELISA. The crossreaction of buckwheat with Wga immune serum showed similar groups (epitopes) which can sensitize cell receptors of patient and as a result can cause allergy, too.

\section{Materials and methods}

\subsection{Materials}

Samples. Whole meal flours of Triticum aestivum cultivar GK Öthalom (wheat variety), Novodur of durum wheat (semolina), Triticum spelta, Chinese spring wheat cultivar, Triticum monococcum. The investigated materials were: buckwheat flour, buckwheat products, pancake, bread from 100\% buckwheat, buckwheat flour dehulled properly, wheat germ lectin, lentils lectin, soya, yellow pea, French buckwheat flour, buckwheat from Slovenia, pancake and muffin made of $100 \%$ buckwheat, muffin made of $100 \%$ wheat flour (AUBRECHT et al., 1998). The samples were commercial products, if variety or species names are not mentioned. 
Sample preparation: The prolamin was extracted from ground sample (100 $\mathrm{mg}$ ) with $1 \mathrm{~cm}^{3}$ of $70 \%$ (v/v) ethanol and Wga was subtracted by PBS in centrifuge tube and extracted with vigorous shaking on a flash shaker (IKA-SCHÜTTLER MTS 4, 700 r.p.m. for $30 \mathrm{~min}$ at $4{ }^{\circ} \mathrm{C}$ ). Following extraction, the samples were centrifuged (T 24 D, 5000 r.p.m. for $20 \mathrm{~min}$ at room temperature), the supernatant was separated and used for ELISA (SZAMOS et al., 1998).

Chemicals. N-acetyl-D-glucosamin, acrylamide, N-N'-methylene bisacrylamide, N,N,N',N'-tetramethyl-ethylenediamine, absolute ethanol, gliadin Fluka Co, wheat germ agglutinin lectin (Sigma Co.), 3,3',5,5'-tetramethyl benzidine (TMB) substrates were used. All other chemicals were of analytical grade.

Reagents for ELISA. Immune sera (anti-gliadin, anti Wga-immune serum) were developed in the Central Food Research Institute. Antigliadin-rabbit IgG and antigliadin-rabbit IgG-HRP conjugates were prepared.

Gel electrophoresis. SDS-PAGE was carried out according to LAEMMLI (1970), acid-PAGE by method of JANSEN and co-workers (1994).

Reagents for immunoblot. Methanol and other chemicals were bought from Reanal Co. The immunoblot membrane was purchased from Millipore Co.

\subsection{Methods}

Immunization protocol. It was carried out according to CUADRADO and coworkers (1998). Competitive indirect method to detect Wga concentration: Plates coated overnight at $4{ }^{\circ} \mathrm{C}$ with $0.5 \mu \mathrm{g} \mathrm{ml}^{-1} \mathrm{Wga}$ ( in sodium carbonate-bicarbonate buffer, $\mathrm{pH}$ 9.8) were washed three times with PBST $(0.01 \mathrm{M}$ phosphate buffer $0.9 \%(\mathrm{w} / \mathrm{v}) \mathrm{NaCl}$ $0.01 \%(\mathrm{v} / \mathrm{v})$ Tween $20, \mathrm{pH} 7.4)$. Then $0.2 \mu \mathrm{l} /$ well of PBSG $(0.01 \mathrm{M}$ phosphate-buffered saline containing $0.5 \%$ gelatine) was added and after incubation for $1 \mathrm{~h}$ at $37{ }^{\circ} \mathrm{C}$ the plates were washed three times with PBST. After this, $100 \mu \mathrm{l} /$ well standard Wga diluted in PBS containing $0.1 \mathrm{M} \mathrm{N}$-acetyl-glucosamine or buckwheat or whole meal wheat flours samples (diluted in $0.1 \mathrm{M} \mathrm{N}$-acetyl-glucosamine in BPS) $50 \mu \mathrm{l} /$ well of polyclonal anti-Wga IgG antibody (1:1000 in PBS) were prepared. After incubation for $1 \mathrm{~h}$ at $37{ }^{\circ} \mathrm{C}$, the plates were washed with PBS. The anti rabbit goat IgG HPR-conjugatum 1:8000 was added. After at $1 \mathrm{~h} 37{ }^{\circ} \mathrm{C}$ incubation the plates were washed three times with PBS. The plates were dried, then $0.1 \mathrm{ml}$ of a solution of OPD- $\mathrm{H}_{2} \mathrm{O}_{2}\left(0.34 \mathrm{mg} \mathrm{m}^{-1}\right.$ o-phenylene-diamine in $0.05 \mathrm{M}$ phosphate-citrate buffer, $0.03 \%(\mathrm{v} / \mathrm{v})$ hydrogen peroxide, $\mathrm{pH} \mathrm{5.0)}$ was added to each well. After $5 \mathrm{~min}$, the reaction was stopped by adding $0.05 \mathrm{ml}$ of $2 \mathrm{M} \mathrm{H}_{2} \mathrm{SO}_{4}$, and the optical density was measured at $492 \mathrm{~nm}$ using Dynatech plate reader. The lectin content of the samples was estimated by $\mathrm{Y}=\mathrm{a} \ln (\mathrm{x})+\mathrm{b}$.

Sandwich ELISA (SKERRITT \& HILL, 1990) modified by AUBRECHT and TÓTH (1995) was used. 
SDS-polyacrylamide gel electrophoresis was carried out as described by LAEMMLI (1970). Acid-PAGE was performed according to JANSEN and co-workers (1994). Immunoblot method used was as of HERIAN and co-workers (1990).

\section{Results}

Protein bands of buckwheat flours were compared to papillionaceous plant seeds and wheat flour and studied by SDS-PAGE. The electrophoretograms of whole proteins of wheat flours and buckwheat flours can be seen in Fig. 1. lane 2 and 5, 6, 7.

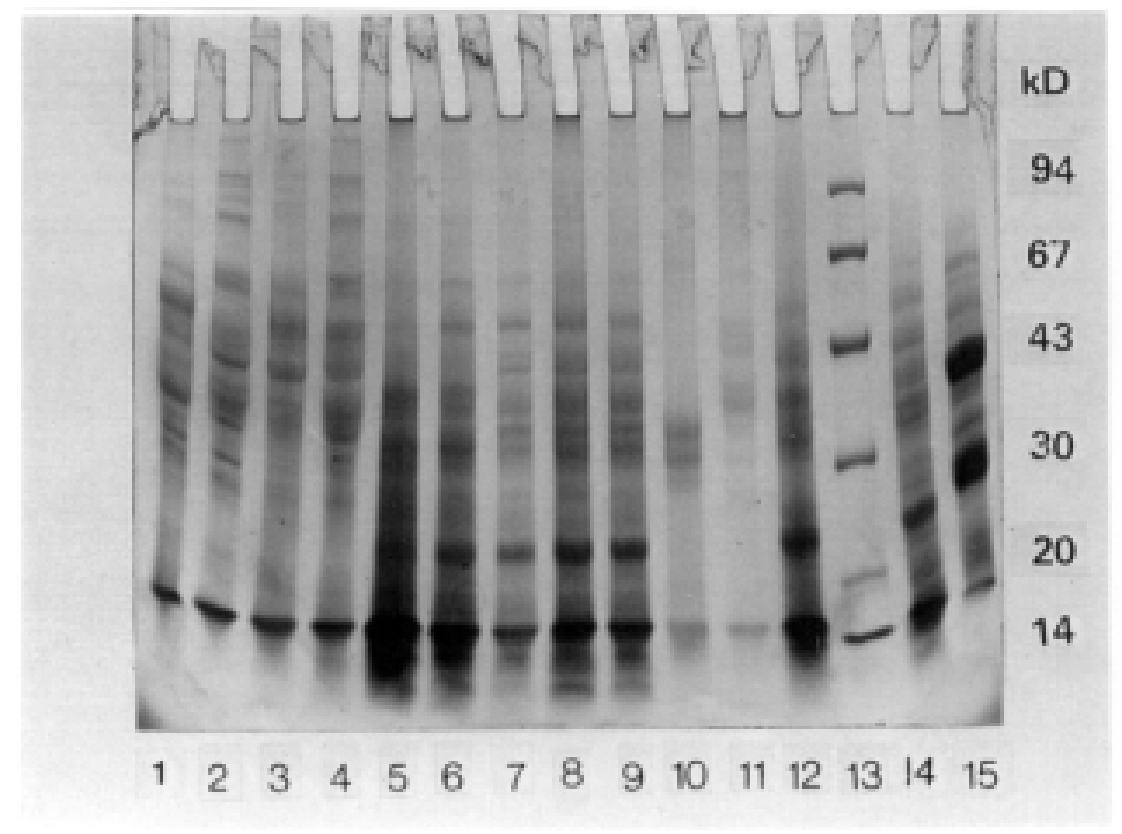

Fig. 1. SDS-PAGE of the total protein of buckwheat flours, their products and papillionaceous plants. Lane 1: bean; lane 2: GK Öthalom wheat variety; lane 3: soya; lane 4: yellow pea; lane 5: buckwheat flour; lane 6: buckwheat flour from France; lane 7: buckwheat from Slovenia; lane 8: pancake made of 100\% buckwheat; lane 9: pancake made of 100\% buckwheat; lane 10: muffin made of 100\% buckwheat; lane 11: muffin made of $100 \%$ wheat flour; lane 12: pasta made of $100 \%$ buckwheat; lane 13: mol weight standard; lane 14: buckwheat seed; lane 15: oat bran 
The electrophoretograms of buckwheat were compared to wheat and to papillionaceous (bean) plant proteins (Figs 2, 3, and 4). Wheat proteins compared to buckwheat do not contain similar protein bands with buckwheat as it can be seen in Figs 3 and 2. Electrophoretogram of bean resembles buckwheat protein, the fractions compared are marked on Figs 4 and 2.

Unlike wheat gliadin the corresponding buckwheat fraction was not electrophoretically resolvable neither into gliadin-like bands on lactate-buffered polyacrilamide gels nor on sodium dodecyl sulfate polyacrilamide gels, it only had minor components in the gliadin molecular size range. The protein bands of buckwheat were diffuse, and wheat gliadin gave three different protein bands.

The prolamin content of buckwheat and wheat flour was measured by ELISA using polyclonal anti-rabbit serum. Optical density of buckwheat flour protein was 0.353 , while the optical density of products which were made of $100 \%$ buckwheat like bread and pancake were measured at 0.179 and 0.268 , respectively. Wheat flour absorbance was 1.241. Ten samples were measured and the standard deviation was under $10 \%$. Estimated prolamin content of buckwheat was ranging from $3.8 \mathrm{mg} \times 100 \mathrm{~g}^{-1}$ dry material to $5.2 \mathrm{mg} \times 100 \mathrm{~g}^{-1}$ on a dry material basis. The prolamin content of buckwheat flour and products (pancake and bread) made of $100 \%$ buckwheat flour was well below the permitted limit (100 $\mathrm{mg} \mathrm{kg}^{-1}$ dry matter basis (FAO/WHO, 1998).

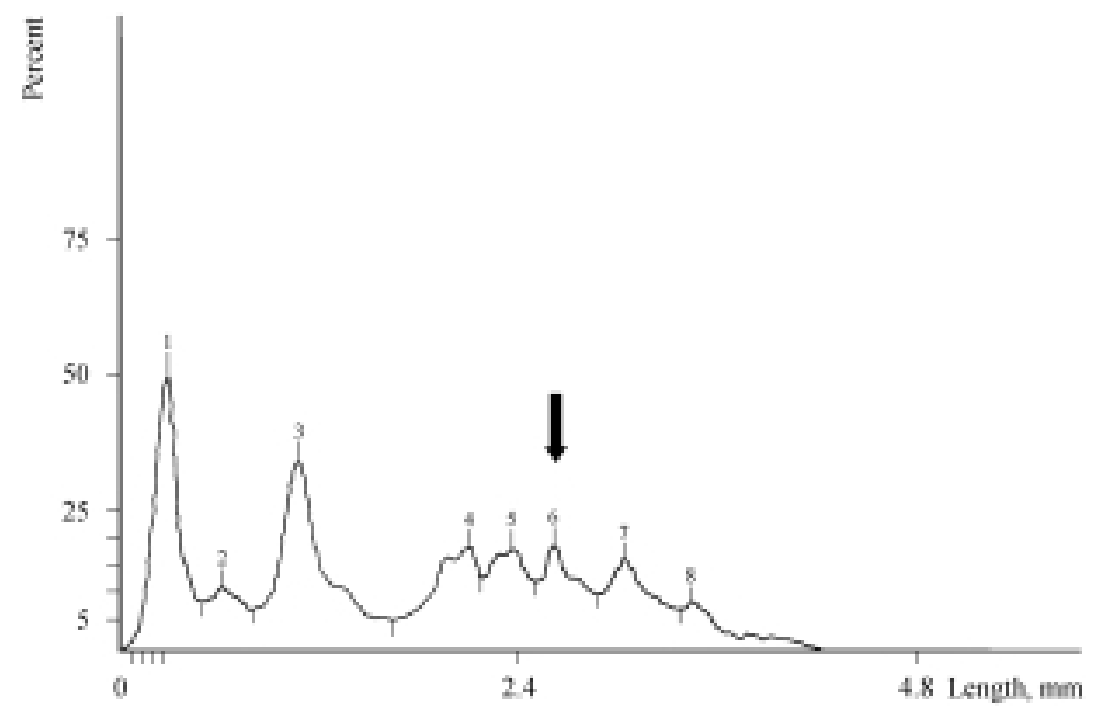

Fig. 2. Electrophoretogram of buckwheat 


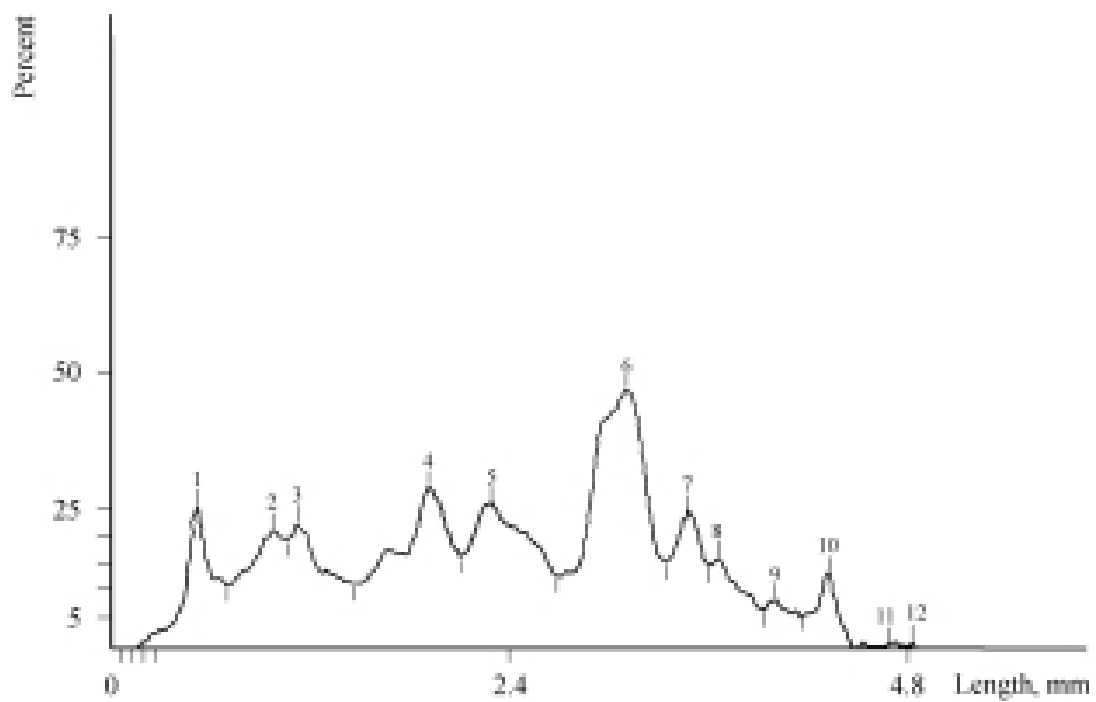

Fig. 3. Electrophoretogram of wheat flour

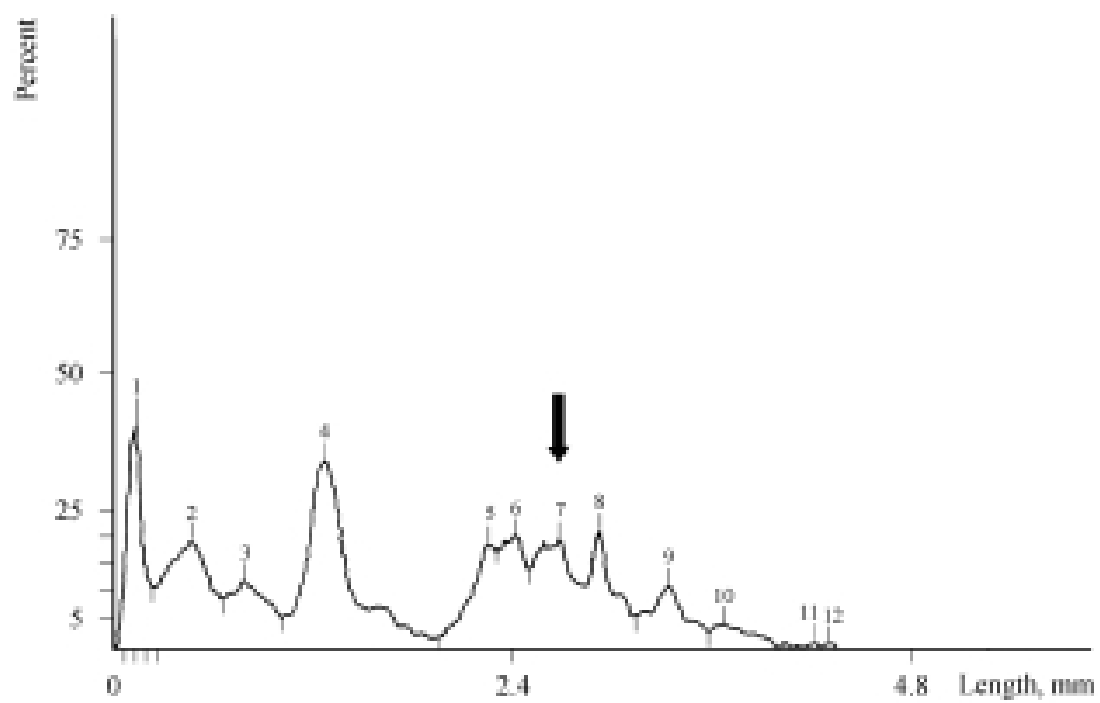

Fig. 4. Electrophoretogram of papillionaceous plants (bean)

Wga lectin can cause allergic reaction to susceptible patients, the allergic activity of buckwheat was characterised with cross-reaction of anti-Wga immune-serum.

Acta Alimentaria 30, 2001 
With polyclonal Wga serum the presence of wheat germ lectin or its homologous structure in buckwheat flour was tested. Buckwheat grain with inner layer membrane reacted with anti-Wga immune serum. Properly hulled buckwheat, however, does not react to anti-Wga immune serum. The immunochemical reaction of positive sample (Triticum monococcum, durum wheat, Triticum aestivum) of grits of cereals can be seen in (Fig. 5 lane 7, 6, 4). The immunochemical reaction of gliadin fraction (Fig. 5 lane 2) with immune serum revealed three different bands. It proved that gliadin has homologous structure with wheat germ lectin. These lectin fractions are glycoproteins which proved that in vitro digested wheat gliadins can easily be separated by affinity chromatography of N-acetyl-glycosamine (DE-VINCENZI et al., 1995). Lentils (Fig. 5 lane 3,8 ) have epitopes similar to wheat germ lectins.

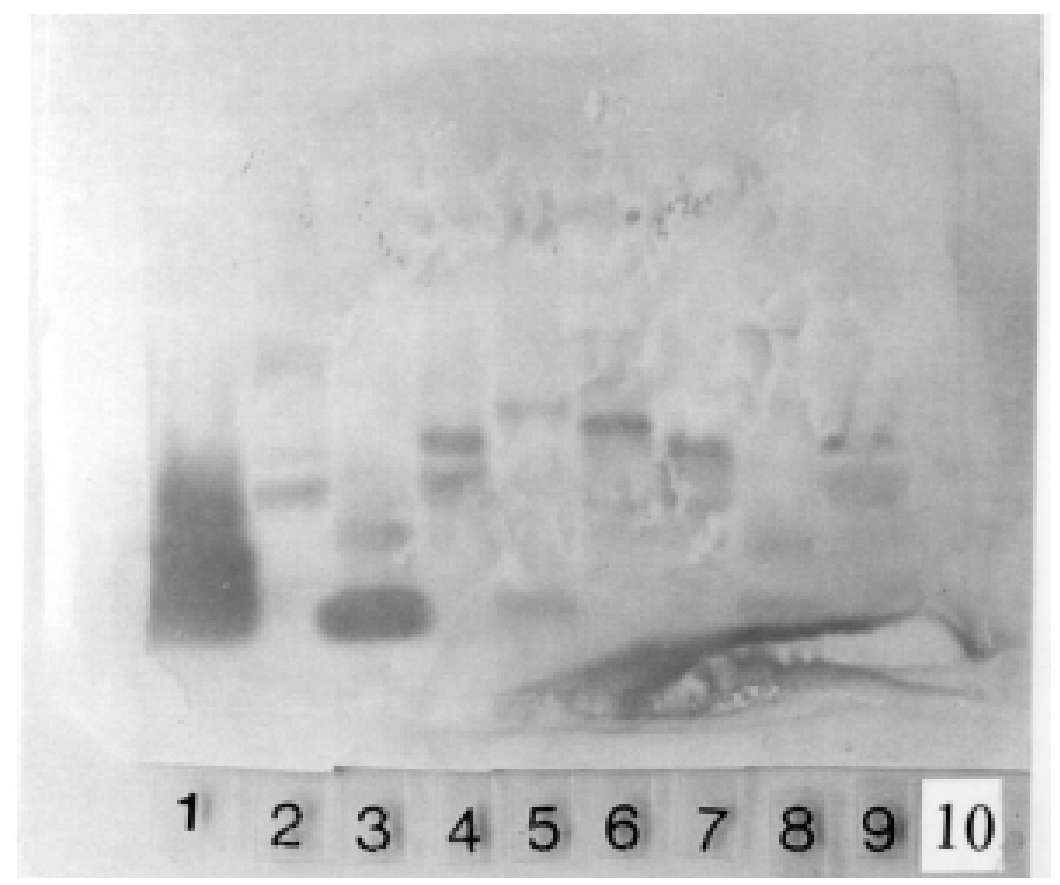

Fig. 5. Immunoblot of anti-wheat germ lectin serum with different plant proteins. The total grain run on $10 \%$ SDS-PAGE gel demonstrating specificity of anti-Wga serum and cross-reaction with homologous structure. Lane 1: wheat germ lectin; lane 2: wheat gliadin; lane 3: lentil lectin; lane 4: whole ground wheat gain GK Öthalom; lane 5: hulled buckwheat seed with inner layer membrane; lane 6: semolina Novodur; lane 7: Triticum monococcum; lane 8: ground lentil; lane 9: buckwheat flour; lane 10: buckwheat flour hulled properly 
The quantity of Wga and its homologous structure were measured by competitive indirect ELISA with the results set forth in Table 1. Properly hulled buckwheat grain does not react with anti-Wga lectin serum or its lectin concentration is very low (Fig. 5 lane 10). The difference between the two type of hulled buckwheat was significant $(\mathrm{P}=0.05)$. The wheat flours GK Öthalom and GK Tiszatáj did not contain any Wgalectin (Table 1). Wheat grits and hulled buckwheat flour with inner layer membrane reacted with the immune serum. The inner layer membrane of buckwheat contains homologous structure with Wga since it gave cross-reaction with anti-wheat germ lectin immune serum (Fig. 5 lane 5 and 9, Table 1). No toxic concentration of Wga lectin or its homologous structure has been identified yet. It would be important to know the maximal non-toxic concentrations if buckwheat flour was regularly used in coeliac diet.

Table 1

Wheat germ agglutinin and its homologous concentration measured by indirect competitive ELISA with anti-wheat germ lectin immune serum

\begin{tabular}{lccc}
\hline Plant varieties & $\begin{array}{c}\text { Wga concentration } \\
\left.\text { in flour }(\mu \mathrm{g} \mathrm{ml})^{-1}\right)\end{array}$ & $\begin{array}{c}\text { Wga concentration } \\
\text { of grist }\left(\mu \mathrm{g} \mathrm{m} l^{-1}\right)\end{array}$ & $\begin{array}{c}\text { Whole meal } \\
\left.(\mu \mathrm{g} \mathrm{m})^{-1}\right)\end{array}$ \\
\hline $\begin{array}{l}\text { Gk Öthalom wheat variety } \\
\text { Barley }\end{array}$ & $1.413 \cdot 10^{-5}$ & 5.915 & 4.764 \\
Gk Tiszatáj wheat variety & - & $3.535 \cdot 10^{-5}$ & 1.042 \\
Buckwheat hulled properly & $1.03 \cdot 10^{-5}$ & 13.59 & 2.21 \\
Buckwheat hulled containing inner layer membrane & 0.089 & - & nd \\
Wheat germ & 110 & nd & - \\
\hline
\end{tabular}

-: not investigated

nd: no detected

\section{Conclusions}

Immunological studies with anti-gliadin rabbit polyclonal antibodies showed little cross-reactivity between wheat prolamins and buckwheat proteins.

Results suggest that alcohol soluble buckwheat proteins bear little molecular similarity to wheat prolamins. While it is possible that components in buckwheat (such as polyphenols) may decrease extraction of gluten-like proteins from buckwheat, this is unlikely to account for the failure to observe such proteins, because a wide variety of extractans (acidic, alkaline, alcoholic and SDS-based) were used in these studies by SKERRITT (1986). In our study prolamin concentration or cross-reaction of buckwheat and their products were under the permitted limit $100 \mathrm{mg}$ gliadin $\mathrm{kg}^{-1}$ on dry material 
basis (FAO/WHO, 1998). RADOVIC and co-workers (1999) found that the buckwheat does not contain any prolamin, but has antinutritive effect and allergen activity for sensitive patients.

It is known that $24 \mathrm{kDa}$ protein bands can cause allergic reaction (KONDO et al., 1996). Studies with heat-treated $100 \%$ buckwheat product showed that $24 \mathrm{kD}$ protein band disappears and form $36 \mathrm{kD}$ aggregate (AUBRECHT \& BIACS, 1999).

The buckwheat grain hulled properly will be suitable for use in coeliac diet after clinical trial (FRANCISCHI et al., 1994a,b).

The authors wish to thank Dr. É. GELENCSÉR for her kind advice and for providing us with chemicals, and suggestions. The efficient technical assistance of Ms. E. SZERDAHELYI, Ms. É. VALENTIN and Ms. C. MOLNÁR are greatly acknowledged.

\section{References}

AUBRECHT, E. \& TÓTH, Á. (1995): Investigation of gliadin content of wheat flour by ELISA method. Acta Alimentaria, 24, 23-29.

AUBRECHT, E., \& BIACS, P. Á. (1999): Immunochemical analysis of buckwheat proteins, prolamins and their allergenic character. Acta Alimentaria, 28, 261-268.

AUBRECHT, E., LÉDER, F., SCHUSTERNÉ GAJZÁGÓ, I., ADÁNYINÉ KISBOCSKÓI, N. (1998): Gluténmentes élelmiszerek körének bővítése új hajdina lisztből készített termékekkel. (New gluten-free food products prepared from buckwheat flour). Táplálkozás - Anyagcsere - Diéta, 3, 3-4.

CuAdrado, C., BurbanO, C., GelenCSÉR, É., GraNT, G. \& PuSzTAI, Á. (1998): Large scale purification of lectin from lentil seeds and determination of the lectin content in processed lentils. Cost 99 Effects of antinutrients on the nutritional value of legume diets. Proceedings of the fourth science workshop in Madrid, 21 September 1996. pp. 82-89.

De-VinCEnZI, M., DeSSI, M. R., GIOvANNINI, C., MAiAletti, F., \& MANCINI, E. (1995): Agglutinating activity of wheat gliadin peptide fractions in coeliac disease. Toxicology, 96, 29-35.

FAO/WHO (1998): ALINORM 97/26, Appendix V. Codex Alimentarius Commission FAO/WHO Food Standard Programme. Codex Committee on Nutrition and Foods for Special Dietary Uses. Twenty first Session, Berlin, Germany, 21-25 September, 1998. Draft, Revised Standard for Gluten-free Foods (At step 7 of the procedure)

FrANCISCHI, M. L. P., SALGADO, J. M. \& LEITAO, R. F. F. (1994a): Chemical, nutritional and technological characteristics of buckwheat and non-prolamine buckwheat flours in comparison of wheat flour. $P l$. Foods Hum. Nutr., 46, 323-329

FRANCISCHI, M. L. P., SALgADO, J. M. \& COSTA, C. P. D. (1994b): Immunological analysis of serum for buckwheat feed celiac patients. Pl. Foods Hum. Nutr., 46, 207-211.

HERIAN, A. M., TAYLOR, S. K \& BUSCH, R. K. (1990): Identification of soybean allergens by immunoblotting with sera from soy allergic adults. Int. Archs Allergy appl. Immun., 92, 193-198. 
Hiller, A., MLODECKI, H. \& TOMCZYK, M. (1975): Preliminary characterization of proteins of buckwheat grain by extraction with selected solvents and molecular filtration on Sephadex G-75 gel. Kromatol. chem. Toksikol., 8, 205-208.

IKEDA, K., SAKAGUCHI, T., KUSANO, T. \& YASUMOTO, K.(1991): Endogenous factors affecting protein digestibility in buckweat. Cereal Chem., 68, 424-427.

JANSEN, F. W., BAAIJ, J. A. \& HAGELE, G. H. (1994): Heat treatment of meat products. Detection of modified gluten by SDS-electrophoresis western-blotting and immunochemical staining. Fleischwirtsch., 74, 168-179.

JAVORNIK, B., EGGUM, B. O. \& KREFT, I. (1981): Studies on protein fractions and protein quality of buckwheat. Genetika, 13, 155-119.

KONDO, Y, URISU, A., WADA, E., TSURUTA, M., YASAKI, T., YAMADA, K., \& MASUDA, S. (1996): Allergen analysis of buckwheat by the immunoblotting method. Jap. J. Allergology, 42, 142-148.

LAEMMLI, U. K.(1970): Cleavage of structural protein during the assembly of the head of bacteriophage $\mathrm{T}_{4}$. Nature, 227, 680-685.

MAKSIMOVIC, V. R., VARKONJI-GASIC, E. I., RADOVIC, S. R. \& SAVIC, A. P. (1996): The biosynthesis of 13S buckwheat seed storage protein. J. Pl. Physiol., 147, 759-761.

RADOVIC, S. R., MAKSIMOVIC, V. R., \& VARKONJI-GASIC, E. I. (1999): Characterization of buckwheat seed storage proteins. J. agric. Fd Chem., 44, 972-974.

SKERRITT, J. H. (1986): Molecular comparison of alcohol-soluble wheat and buckwheat proteins. Cereal Chem., 63, 365-369.

SKERRITT, J. H. \& HILL, A. S. (1990): Monoclonal antibody sandwich enzyme immunoassays for determination of gluten of foods. J. agric. Fd. Chem., 38, 1771-1778.

SZAMOS, J., AUBRECHT, E. \& GELENCSÉR, É., (1998): Detection of wheat by adapted polymerase chain reaction (PCR) methodology. Acta Alimentaria, 27, 87-95.

TIARA, H. (1974): Buckwheat. -in: JONSON, A. M. \& PETERSON, M. J. (Eds) Encyclopedia of food technology. Avi Publ. Co. Wesport, C. T. p. 139.

WEI, Y. M., ZHANG, G. Q. \& LI, Z. X. (1995): Study on nutritive and physico-chemical properties of buckwheat flour. Nahrung, 39, 48-54. 